\title{
Correction to: How Total Factor Productivity Drives Long-Run Energy Consumption in Saudi Arabia
}

Fakhri J. Hasanov, Brantley Liddle, Jeyhun I. Mikayilov and Carlo Andrea Bollino

\section{Correction to:}

Chapter "How Total Factor Productivity Drives Long-Run Energy Consumption in Saudi Arabia" in: M. Shahbaz and D. Balsalobre (eds.), Energy and Environmental Strategies in the Era of Globalization, Green Energy and Technology, https://doi.org/10.1007/978-3-030-06001-5_8

In the original version of the book, the Chapter "How Total Factor Productivity Drives Long-Run Energy Consumption in Saudi Arabia" was not published under the open access category. The category has been changed. The erratum chapter and book have been updated. 